\title{
An Examination of Perceived Factors of Influencing Mass Killings in the United States of America
}

\author{
Stephone K. Addison \\ Department of Criminal Justice and Criminology \\ Nelson Mandela College of Government and Social Sciences \\ Southern University and A \& M College, Baton Rouge, LA.
}

\begin{abstract}
The criminal justice system in USA has undergone through series of attack from the citizens with specific references from the numerous incidences of crime cases due to mass killing, and legalization of gun holding policies. According to Folman, Aronsen, and Pan (2018), in 2018 alone, 12 reported mass shootings in the U.S. Despite gun laws that have been enacted in varying degrees from each state across the country, mass shootings and/or killings is a glaring problem that continues to divide America. The battle over gun control and gun rights increases seemingly after each incident of mass shooting. There are many factors discussed by educators, politicians, legal scholars and laypersons alike regarding the cause of mass shootings but little attention has been paid to the issue. This study investigates and examine the relationship between the number mass killings and race, gender, political party affiliation, use of assault weapons and mental illness. This research uses linear regression, correlation, and secondary sources of data covering the periods between $2016-2018$. The study finds a strong positive relationship between mass killings and race. However, a statistically significant relationship to the number of mass killings and political party affiliation is lacking. Also lacking is a statistically significant relationship between mass killings and mental illness. Perhaps the latter is due to failure or inability to appropriately diagnose those who engage in mass shootings and/or killings as being mentally ill. Therefore, the study recommends that the mental health agencies and professionals should identify ways to communicate to active patients, their family members and the community-at-large on proper recognition of signs of mental illness and appropriate means to report such signs in order to minimize crime in USA.
\end{abstract}

Keywords: Race, Politics, Mass Killing, Correlation, Political Party, Crime and Justice System

DOI: $10.7176 / \mathrm{JLPG} / 104-08$

Publication date: December $31^{\text {st }} 2020$

\section{INTRODUCTION}

In February 2018, an upstate New York member of Congress, Rep. Claudia Tenney, R-Utica, made national headlines when she suggested many mass shooters were Democrats (Clark \& Specht, 2018). On a radio show, Representative Tenney made a statement that "many of the people that commit the mass murders end up being Democrats." The statement made by Rep. Tenney follows a growing concern for what appears to be a rise in mass shootings and/or mass killings in the U.S. Several factors have been posited regarding the reason for this phenomenon. Those factors include easy access to guns, unemployment, mental health, etc.

Today's media, albeit the mainstream news (print or television), social media, etcetera, appears to be inundated with reports regarding incidents of gun violence. Recent reports such as the Texas church shooting, Las Vegas concert shooting, Orlando night club shooting, and Sandy Hook Elementary school shooting in 2012 (Cummings and Janson, 2017), suggest an uptick in fatalities resulting from the use of assault rifles. From the period of 1993 - 2011, firearm (gun) violence account for about $70 \%$ of all homicides in the United States (Planty and Truman, 2013). "From 2009-2016 in the U.S., there have been 156 mass shootings-incidents in which four or more people were shot and killed, not including the shooter" (Mass Shootings in the United States: 2009 - 2016, 2017). Recently however, the Federal Bureau of Investigation (FBI) under auspices of the Department of Justice began collecting data and compiled into the Active Shooter Incidents Report. In the year 2016 - 2017 twenty (20) of the fifty (50) Active Shooter Incidents (ASI) met the criteria cited in the federal definition of "mass killings," that is, "three or more killings in a single incident." (Justice, 2018). Also, ASI took place various states across the country (see Figure 1 for more details). While to some, the foregoing statistics may appear alarming, there still remains to be a continuing debate in the U.S. regarding control laws and policy. Firearms or guns have been a part of the fabric of American society from its inception. Also, while the debate goes on, gun violence by the way of mass killings appear to be steadily on the rise. This brings us to the focus of this research and that is: what is causing the behavior of mass killing? Thus, this research is designed to examine the correlation between mass killings and race, gender, political party affiliation, use of assault weapons and mental illness. The result of the study is intended to provide insight and guidance on ways of addressing and perhaps reducing the incidents of mass killings. Also, recommendations regarding future policy and practice relative to mass killings will be offered. 


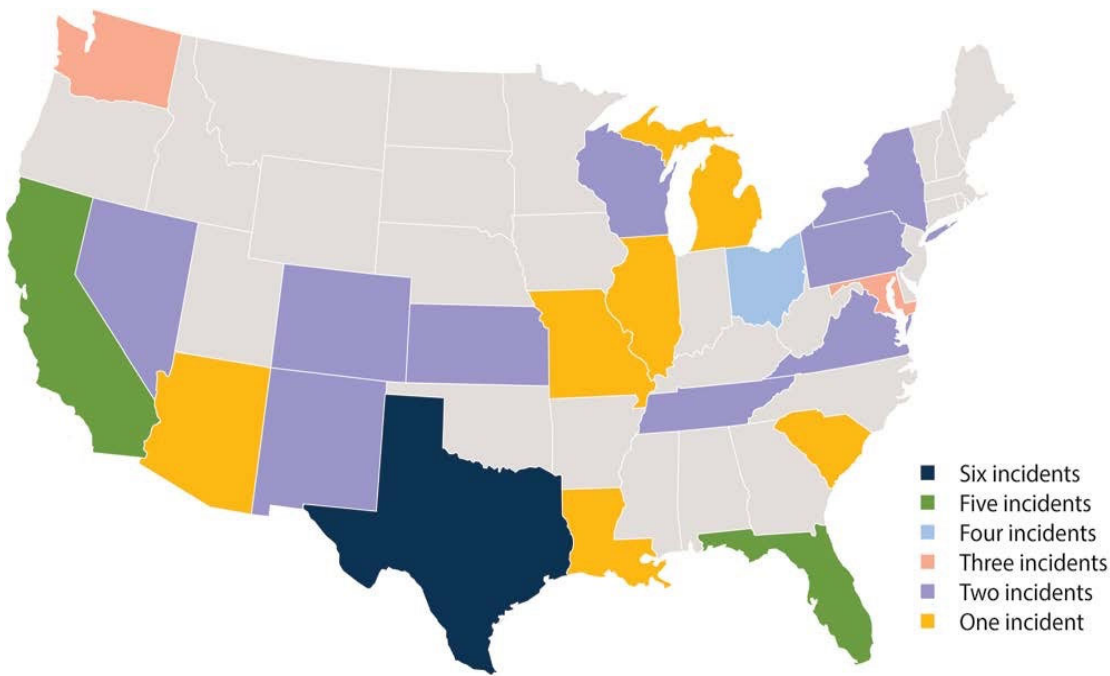

Figure 1: States with Active Shooter Incidents 2016 - 2017

Source: DOJ: FBI

\section{LITERATURE REVIEW}

Much have been written and debated regarding the influences and/or causes for the plethora of mass shootings (as defined by FBI) in the U.S. over the past decades. Some evidence has pointed to the fact that the shooting at Sandy Hook elementary as well as the shooting at Virginia Tech University was a result of copycat behavior influenced by the Columbine shooting (Schildkraut, 2018). In various media reports citing causes of mass shootings, mental illness has also been cited as a contributing factor (Rees, Lee, Fleegler, \& Mannix, 2019). Other themes associated with mass shootings particularly as it relates to more deadlier killings involved the use of military like assault rifles (Jenkins, 2018). Also in the area of types of weapons used, results of studies have found relationships in the banning of certain types of weapons and the reduction in fatalities (Klarevas, Conner, \& Hemenway, 2019).

Klarevas, et al. (2019), conducted a study focusing attention on the effect of large capacity magazine (LCM) bans on the frequency and lethality of high-fatality mass shootings. They assessed the relationship between LCM bans overall as well as separate assessments on federal and state bans. A logit regression analysis was used on the occurrence of high-fatality mass shootings and for deaths resultying from those incidents, a negative binomial analysis was used. Results of the study showed that between 1990 and 2017, a higher rate in the incidence or occurrence of high-fatality mass shootings and annual death rates were more than 3 times higher in states without LCM bans, therefore suggesting that LCM bans tend to reduce the incidences and number of deaths in high-fatality mass shootings.

Finally, the subject of race has been a part of the discussion when it comes to mass shootings. While it is difficult to conclude that one's race is the cause of the behavior associated with mass shootings, some studies may indicate that frequency of occurences in high profile mass shootings may point in the direction of certain racial groups over others (Metzl \& MacLeish, 2015). Although there has been ongoing debate over factors, individual and societal, which causes or are more likely lead to mass shootings, one thing in which there can be no debate is that factors causing incidences of mass shootings and ways to prevent them should continue to be studied.

\section{METHODOLOGY}

This research utilizes both quantitative research design and multiple linear regression model. To analyze the data used in the study, both nominal and ratio scale variables were used. The method used to analyze the relationship between the number of Mass Killings and race, gender, political party affiliation, type of weapon used, and mental illness was the Ordinary Least Square (OLS) method. Also, the data used in the study was taken from secondary sources which included the FBI's Active Shooter Incidents Report from 2016 - 2017 (Justice, 2018) and a report from Mother Jones: A Guide to Mass Shootings in American for the year 2018 (Folman, Aronsen, \& Pan, 2018). This study follows the Heij, de Boer, Franses, Kloek, and Dijk (2004) linear regression model stated below as:

$$
\mathrm{Yi}=\beta \mathrm{o}+\beta_{1} \mathrm{Xi}+\beta_{2} \mathrm{Xi}+\beta_{3} \mathrm{Xi} \ldots+\varepsilon \mathrm{i}
$$

In this model, $\boldsymbol{Y}$ represents the dependent variable (number of mass killings), $\mathbf{X}$ represents the independent variable(s) (race, gender, political party, assault weapons used and mental illness). Also, where $\beta$ o is the constant term or average, and the $\beta$ 's are the coefficients for the independent variables. However, before review and discussing the results of the model to be used for decision making, a discussion of the study hypotheses is appropriate at this point. As part of the study design, researcher examine the hypothesis that there is no statistical relationship between number of mass killings and race, gender, political party, assault weapons used and mental 
illness. The examination of this particular hypothesis will enable the researcher to get enough evidence to better inform the criminal justice system.

\section{RESULTS}

The results of this study will be discussed in three main parts: 1) A summary of descriptive statistics, 2) Correlation analysis, and 3) Regression (model summary, analysis of variance and and coefficient analysis):

\section{Table 1: Summary of Descriptive Statistics}

Descriptive Statistics

\begin{tabular}{|c|c|c|c|c|c|c|c|c|c|}
\hline & $\mathrm{N}$ & Minimum & Maximum & Mean & Std. Deviation & \multicolumn{2}{|c|}{ Skewness } & \multicolumn{2}{|c|}{ Kurtosis } \\
\hline & Statistic & Statistic & Statistic & Statistic & Statistic & Statistic & Std. Error & Statistic & Std. Errol \\
\hline Race & 26 & 0 & 1 & .54 & .508 & -.164 & .456 & -2.145 & .887 \\
\hline Gender & 26 & 0 & 1 & .96 & .196 & -5.099 & .456 & 26.000 & .887 \\
\hline Political Party & 26 & 0 & 0 & .00 & .000 & & & & \\
\hline Assault Weapons Used & 26 & 0 & 1 & .50 & .510 & .000 & .456 & -2.174 & .887 \\
\hline $\begin{array}{l}\text { Diagnosed with Mental } \\
\text { Illness }\end{array}$ & 26 & 0 & 1 & .19 & .402 & 1.659 & .456 & .807 & .887 \\
\hline Valid N (listwise) & 26 & & & & & & & & \\
\hline
\end{tabular}

\section{Source of Data: Field data 2020}

A summary of the descriptive statistics reflects twenty-six (26) samples or units of analysis being observed and analyzed. Based on the summary most of the shooters were male having a mean of $96 \%$ with a standard deviation of $.196(19.6 \%)$. About half of the weapons used were assault weapons with a mean of (50\%). Also, slightly over half $(54 \%)$ of the mass shootings were done by white males.

Table 2: Correlation Between Number of Mass Killings and Other Variables in the Study

\begin{tabular}{|c|c|c|c|c|c|c|c|}
\hline & & $\begin{array}{l}\text { Number of } \\
\text { Mass Killings }\end{array}$ & Race & Gender & Political Party & $\begin{array}{c}\text { Assault } \\
\text { Weapons } \\
\text { Used }\end{array}$ & $\begin{array}{c}\text { Diagnosed } \\
\text { with Mental } \\
\text { Illness }\end{array}$ \\
\hline Pearson Correlation & $\begin{array}{l}\text { Number of Mass Killings } \\
\text { Race } \\
\text { Gender } \\
\text { Political Party } \\
\text { Assault Weapons Used } \\
\text { Diagnosed with Mental } \\
\text { Illness }\end{array}$ & $\begin{array}{r}1.000 \\
.427 \\
. \\
.000 \\
-.043\end{array}$ & $\begin{array}{r}.427 \\
1.000 \\
. \\
. .328 \\
-.201\end{array}$ & 1.000 & 1.000 & $\begin{array}{r}.000 \\
-.328 \\
. \\
.000 \\
.357\end{array}$ & $\begin{array}{r}-.043 \\
-.201 \\
. \\
.357 \\
.000\end{array}$ \\
\hline Sig. (1-tailed) & $\begin{array}{l}\text { Number of Mass Killings } \\
\text { Race } \\
\text { Gender } \\
\text { Political Party } \\
\text { Assault Weapons Used } \\
\text { Diagnosed with Mental } \\
\text { Illness }\end{array}$ & $\begin{array}{r}. \\
.030 \\
.000 \\
.000 \\
.500 \\
.428\end{array}$ & $\begin{array}{r}.030 \\
.000 \\
.000 \\
.079 \\
.198\end{array}$ & $\begin{array}{r}.000 \\
.000 \\
.000 \\
.000 \\
.000\end{array}$ & $\begin{array}{r}.000 \\
.000 \\
.000 \\
.000 \\
.000\end{array}$ & $\begin{array}{r}.500 \\
.079 \\
.000 \\
.000 \\
.061\end{array}$ & $\begin{array}{l}.428 \\
.198 \\
.000 \\
.000 \\
.061\end{array}$ \\
\hline $\mathrm{N}$ & $\begin{array}{l}\text { Number of Mass Killings } \\
\text { Race } \\
\text { Gender } \\
\text { Political Party } \\
\text { Assault Weapons Used } \\
\text { Diagnosed with Mental } \\
\text { Illness }\end{array}$ & $\begin{array}{l}20 \\
20 \\
20 \\
20 \\
20 \\
20\end{array}$ & $\begin{array}{l}20 \\
20 \\
20 \\
20 \\
20 \\
20\end{array}$ & $\begin{array}{l}20 \\
20 \\
20 \\
20 \\
20\end{array}$ & $\begin{array}{l}20 \\
20 \\
20 \\
20 \\
20\end{array}$ & $\begin{array}{l}20 \\
20 \\
20 \\
20 \\
20\end{array}$ & $\begin{array}{l}20 \\
20 \\
20 \\
20 \\
20\end{array}$ \\
\hline
\end{tabular}

Source of Data: Field Data 2020

Due to the independent variables gender and political party affiliation being identified as constants, they were not included in the correlation analysis. However, with respect to the correlation analysis between the variables the following was observed. With a P-Value of 0.03 , there is a strong positive relationship between the number of mass killings and race. Most mass killing were found to have been committed by Caucasian (white) males. Also, with a P-Value of 0.500 , there is not a statistically significant relationship between the number of mass killings and the use of assault weapons and therefore findings fail to reject the null hypothesis. With a P-Value of 0.061, there is a (weak) but statistically significant relationship between the number of Assault Weapons used and diagnosis with mental illness. With a P-Value of 0.079 , there is a (weak) but statistically significant relationship between the number of Assault Weapons used and race. 
Table 3: Correlation Between Number of Mass Killings and Variables included in the Study Model Summary

\begin{tabular}{|l|l|r|r|r|}
\hline Model & $\mathrm{R}$ & $\mathrm{R}$ Square & \multicolumn{1}{c|}{$\begin{array}{c}\text { Adjusted R } \\
\text { Square }\end{array}$} & $\begin{array}{c}\text { Std. Error of } \\
\text { the Estimate }\end{array}$ \\
\hline 1 & $.452^{\mathrm{a}}$ & .204 & .055 & 5.750 \\
\hline
\end{tabular}

a. Predictors: (Constant), Diagnosed with Mental IIIness, Race,

Assault Weapons Used

Upon analysis of the model summary above (Table 3), reflecting the overall predicting power of the model (R-Square) reflects about 20\% (0.204) predictability of the strength of the variables used. Therefore, there is about $80 \%$ variation. This suggest that only $20 \%$ of mass killings is explained by race, assault weapons used and mental illness. Hence, there are other relevant factors that may explain the number of mass killings. Perhaps another reason for the low predictability of the variables used could be in how mental illness was tested in the study. In other words, mental illness used in this instance was defined as those who were medically diagnosed as mentally ill prior to the shooting/killing as opposed persons merely showing signs of mental illness.

Table 4: Regression Coefficients Estimation for Mass Killing

\begin{tabular}{|c|c|c|c|c|c|c|}
\hline \multirow{2}{*}{\multicolumn{2}{|c|}{ Model }} & \multicolumn{2}{|c|}{ Unstandardized Coefficients } & \multirow{2}{*}{$\begin{array}{c}\begin{array}{c}\text { Standardized } \\
\text { Coefficients }\end{array} \\
\text { Beta }\end{array}$} & \multirow[b]{2}{*}{$t$} & \multirow[b]{2}{*}{ Sig. } \\
\hline & & $B$ & Std. Error & & & \\
\hline \multirow[t]{4}{*}{1} & (Constant) & 7.271 & 2.345 & & 3.101 & .007 \\
\hline & Race & 5.543 & 2.749 & .478 & 2.017 & .061 \\
\hline & Assault Weapons Used & 1.864 & 2.927 & .158 & .637 & .533 \\
\hline & $\begin{array}{l}\text { Diagnosed with Mental } \\
\text { Illness }\end{array}$ & -.055 & 3.457 & -.004 & -.016 & .988 \\
\hline
\end{tabular}

a. Dependent Variable: Number of Mass Killings

An analysis of the coefficients table (Table 4) reflects a very strong positive relationship with the model where the $\mathrm{P}$-value is at $0.7 \%(.007)$ significance. There is a positive albeit weak relationship or level of significance with respect to the number of mass killings and race with a P-value of $6.1 \%(.061)$. However, there is no evidence of statistical significance with respect to assault weapons used with a P-value of $53.3 \%(.533)$ and being diagnosed with mental illness with a P-value of $98.8 \%(.988)$. Thus, the model fails to reject the null hypothesis that there is no statistically significant relationship between Mass Killings and the use of Assault Weapon(s) by the offender. It also fails to reject the null hypothesis that there is no statistically significant relationship between Mass Killings and the offender being diagnosed with mental illness.

\section{CONCLUSION AND POLICY RECOMMENDATION}

Considering the results and analysis of the model, I therefore recommend that mental health agencies and professionals identify ways to communicate to active patients, their family members and the community-at-large on proper mental illness screening techniques. Efforts should be concentrated towards placing more awareness regarding those who are often engaged in mass shootings and/or killings and may be considered high-risk individuals. This will be helpful when it comes to early identification and early intervention. Based on the relationship between assault weapons and mental illness, policy and tougher laws may be needed to assure that those with mental illness problems or symptoms may not have easy access to purchasing assault weapons.

\section{REFERENCES:}

Aitken, L. P. (2008). MASS MURDERS: IMPLICATIONS FOR MENTAL HEALTH PROFESSIONALS. Retrieved May 4, 2018, from Sage Journals: http://journals.sagepub.com/doi/pdf/10.2190/PM.38.3.c

Clark, D., \& Specht, P. (2018, February 23). Do many mass shooters 'end up being Democrats', as Rep. Tenney said? No. Retrieved from Politifact New York: https:/www.politifact.com/newyork/statements/2018/feb/23/claudia-tenney/do-many-mass-shooters-end-being-democrats-rep-tenn/

Cummings, B. J. (2017, November 6). Why mass shooters are increasingly using AR 15s. Retrieved November 27 , 2018, from USA Today: https://www.usatoday.com/story/news/2017/11/06/ar-15-style-rifles-commonamong-mass-shootings/838283001/

Folman, M., Aronsen, G., \& Pan, D. (2018, November 19). US Mass Shootings, 1982-2018: Data From Mother Jones' Investigation. Retrieved from Mother Jones: https://docs.google.com/spreadsheets/d/1b9o6uDO18sLxBqPwl_Gh9bnhWev_dABH83M5Vb5L8o/edit\#gid=0

GROUP1, I. E. (2005). International clinical practice guidelines for early psychosis. Retrieved May 4, 2018, from BRITISH JOURNAL OF PSYCHIATRY: http://umh1946.edu.umh.es/wp- 
content/uploads/sites/172/2015/04/International-clinical-practice-guidelines-for-early-psychosis 1.pdf

Gun Laws. (2017). Retrieved November 25, 2018, from FindLaw: http://injury.findlaw.com/product-liability/gunlaws.html

H.R. 2406 - Share Act. (2017). Retrieved November 25, 2018, from Congress: https://www.congress.gov/bill/114th-congress/house-bill/2406

Heij, C., de Boer, P., Franses, P. H., Kloek, T., \& Dijk, H. K. (2004). Econometric Methods with Applications in Business and Economics. Oxford: University Press.

Justice, U. D. (2018). Active Shooter Incidents in the United States in 2016 and 2017. Retrieved from U.S. Department of Justice: Federal Bureau of investigation: https://www.fbi.gov/file-repository/active-shooterincidents-us-2016-2017.pdf/view

Keneally, M. (2017, October 4). 47 guns, loaded high-capacity magazines found in Vegas shooter's hotel suite and Nevada home. Retrieved November 25, 2018, from abc NEWS: http://abcnews.go.com/US/guns-loadedhigh-capacity-magazines-found-vegas-shooters/story?id=50228093

Las Vegas Shooting. (2017, October 2). Retrieved November 25, 2017, from NBC NEWS: https://www.nbcnews.com/storyline/las-vegas-shooting/las-vegas-police-investigating-shooting-mandalaybay-n806461

Law and Guidance/Elementary and Secondary Education. (2017). Retrieved November 25, 2018, from U.S. Department of Education: https://www2.ed.gov/policy/elsec/leg/esea02/pg54.html

Longley, R. (2017, November 3). See a Timeline of Gun Control in the United States. Retrieved November 25, 2018, from ThoughtCo.: https:/www.thoughtco.com/us-gun-control-timeline-3963620

Mass Shootings in the United States: 2009 - 2016. (2017, April 11). Retrieved November 17, 2017, from Everytown for Gun Safety Support Fund: https://everytownresearch.org/reports/mass-shootings-analysis/ 